\title{
ECOLOGICAL ASPECTS OF MARINE TUCUXI DOLPHINS (SOTALIA GUIANENSIS) BASED ON GROUP SIZE AND COMPOSITION IN THE CANANÉIA ESTUARY, SOUTHEASTERN BRAZIL
}

\author{
Marcos César de Oliveira Santos ${ }^{1, *}$ and Sergio Rosso²
}

\begin{abstract}
Aвstract: Observations on group size and composition of marine tucuxi dolphins, Sotalia guianensis, found in the Cananéia estuary $\left(25^{\circ} 03^{\prime} \mathrm{S}, 47^{\circ} 55^{\prime} \mathrm{W}\right)$, southeastern Brazil, were conducted from May 2000 to July 2003. Correlations among four environmental variables (water temperature, salinity, transparency and depth) and group size were investigated, as well as on the way foraging and feeding behavioral patterns related to group formation in S. guianensis. The surveyed area comprised approximately $132 \mathrm{~km}^{2}$ and field efforts were conducted in 87 days. A total of 378 groups were recorded. Group size (mean \pm SD: $12.4 \pm 11.4$ individuals) varied from lone individuals, rarely seen, to aggregations of up to 60 individuals. No significant differences were found regarding group size among seasons. Groups with calves $(89.7 \%$ of all observed groups) were more frequent than groups without calves. Feeding associations with marine birds were common in winter when waters were clearer. A positive correlation was only reported when investigating group size and water depth (Spearman's rank test, $r=0.4716, p=0.0000$ ). Marine tucuxis usually form large aggregations (20 to 60 individuals) when engaged in feeding activities in deeper waters. Groups were larger (mean \pm SD: $18.3 \pm$ 15.0 individuals, $n=90$ ) in the main estuary entrance, where water is deeper, and smaller in inland shallower waters (mean \pm SD: $7.8 \pm 6.9$ individuals, $n=47$ ). Because of these common observed aggregations, this area of the estuary has been used as a dolphin watching site since the late 1990s without specific regulations. Guidelines are urgently needed to conduct dolphin watching tours as calves are seen year-round and uncontrolled tourism may disrupt important social interactions.
\end{abstract}

Resumo: Observações a respeito do tamanho e da composição de grupos do boto-tucuxi marinho, Sotalia guianensis, encontrados no estuário de Cananéia ( $\left.2^{\circ} 03^{\prime} \mathrm{S}, 4^{\circ} 55^{\prime} \mathrm{W}\right)$, sudeste do Brasil, foram conduzidas entre os meses de maio de 2000 a julho de 2003. Correlações entre quatro variáveis ambientais (temperatura, salinidade, transparência, e profundidade da água) e tamanho de grupos foram investigadas, assim como sobre a forma com que padrões comportamentais relacionados à alimentação poderiam estar relacionados com a formação de grupos em S. guianensis. A área de estudo apresentou aproximadamente $132 \mathrm{~km}^{2}$ e os esforços de campo foram desenvolvidos em 87 dias de investigações. Um total de 378 grupos foi observado. Os tamanhos de grupo (média \pm DP: $12,4 \pm 11,4$ indivíduos) variaram entre indivíduos solitários raramente observados a agregações de até 60 indivíduos. Não foram detectadas diferenças significativas relacionadas aos tamanhos de grupos observados em diferentes estações do ano. Grupos contendo filhotes $(89,7 \%$ de todos os grupos observados) foram mais freqüentes do que os grupos sem filhotes. Associações alimentares com aves marinhas foram comuns no inverno quando as águas são mais claras. Uma correlação positiva foi apenas reportada quando da investigação do tamanho de grupo relacionado à profundidade da água (Teste de Correlação de Spearman, r=0,4716, $p=0,0000$ ). Os botos-tucuxi marinhos geralmente formam grandes agregações (20 to 60 indivíduos) quando envolvidos em atividades alimentares em águas profundas. Os grupos observados foram maiores (média \pm DP: 18,3 $\pm 15,0$ indivíduos, $n=90$ ) na principal entrada do estuário, onde as águas são mais profundas, e menores nas águas internas mais rasas (média 7,8 $\pm 6,9$ indivíduos, $n=47$ ). Por causa da existência dessas agregações comumente observadas, este pequeno setor do estuário tem sido utilizado como uma área para observação de cetáceos desde o final dos anos 1990 sem a existência de regulamentações específicas. Regulamentações são necessárias para a condução de turismo de observação de botos já que filhotes podem ser observados ao longo de todo o ano e o turismo não controlado pode colocar em risco interações sociais de grande importância para a população estudada.

KEYWORDs: group size, marine tucuxi dolphins, Sotalia guianensis, ecology, feeding behavior.

\section{Introduction}

Marine tucuxi dolphins, Sotalia guianensis, occur in coastal and estuarine waters of South and Central America in the Western Atlantic Ocean (da Silva and Best, 1996; Carr and Bonde, 2000; Flores, 2002). Recently, studies addressing the taxonomic status of Sotalia provided evidence that marine (S. guianensis) and riverine ( $S$. fluviatilis) tucuxi dolphins are separate species (Monteiro-Filho et al., 2001; Cunha et al., 2005; Caballero et al., 2007). The marine tucuxi's preference for coastal and estuarine brackish waters, avoidance response to the presence of boats, lack of sexual dimorphism, and small body size compared to other cetacean species make this species relatively difficult to study in its natural habitat (Santos et al., 2000). To date, the biology and conservation status of S. guianensis remain poorly known. As a result, the species is still listed as "data deficient" by the World Conservation Union (IUCN) (Reeves et al., 2003; IUCN, 2006).

Most longitudinal studies with $S$. guianensis have focused on photo-identification (e.g. Flores, 1999; Santos et al., 2001; Azevedo et al., 2004; 2005; Flores and Bazallo, 2004; Flores and Fontoura, 2006), but limited information on ecological aspects has been reported. S. guianensis has been studied in the Cananéia

\footnotetext{
${ }^{1}$ Projeto Atlantis, Laboratório de Biologia da Conservação de Cetáceos, Departamento de Zoologia, Instituto de Biociências da Universidade Estadual Paulista "Júlio de Mesquita Filho" (UNESP), Campus Rio Claro, Av 24-A, 1.515, Bela Vista, Rio Claro, SP, Brazil, 13506-900. E-mail: sotalia@gmail.com

${ }^{2}$ Laboratório de Ecologia Marinha, Departamento de Ecologia, Instituto de Biociências, Universidade de São Paulo, Rua do Matão, 321 , Cidade Universitária, São Paulo, SP, Brazil, 05508-900.

* Corresponding author: Avenida 8, Num. 1837, Apartamento 63, Rio Claro, SP, Brazil, 13506-210.
} 
estuary $\left(\sim 25^{\circ} \mathrm{S}, 48^{\circ} \mathrm{W}\right)$, São Paulo state, southeastern Brazil, where a relatively large population can be found year-round (Santos et al., 2001). Since 1996, several studies have been conducted on various aspects of this population: behavior (Santos et al., 2000), feeding habits (Santos et al., 2002), abundance (Acuña, 2002), age estimation (Santos et al., 2003), contaminant loads (Yogui et al., 2003), social organization (Santos, 2004), and acoustics (Pivari and Rosso, 2005). The aim of the present study was to evaluate the characteristics of $S$. guianensis group size and composition in the Cananéia estuarine waters, as well as to verify the existence of relationship between a given environmental variable (water depth, salinity, transparency and temperature) and group size. These variables were chosen because they have a significant influence on lower trophic level species abundance and distribution in tropical and subtropical estuarine ecosystems, mainly when considering rainy and dry seasons (Day Jr. et al., 1989). As a consequence, top predators adapt the way they use the area through time and space. These factors might influence group formation in S. guianensis in different subsets of the estuary, as well as in coastal waters. Understanding how environmental factors may affect living organisms is relevant to describe the dynamics of the ecosystem and, therefore, for conservation purposes. As the distribution and abundance of prey play a relevant role in the way predators form their groups, behavioral patterns with emphasis on foraging and feeding activities were also investigated when evaluating group sizes.

\section{Material and Methods}

\section{Study area}

The Cananéia estuary is located at the southern coast of São Paulo state $\left(25^{\circ} 03^{\prime} \mathrm{S}, 47^{\circ} 55^{\prime} \mathrm{W}\right)$, Brazil, and is part of a $180 \mathrm{~km}$ long estuarine system. The estuary is characterized by a muddy bottom and shallow waters (up to $23 \mathrm{~m}$ ) that can be relatively turbid year-round (Schaeffer-Novelli et al., 1990). High concentrations of nutrients, zooplankton, shrimp and fish can be found year-round in this ecosystem, which is surrounded by large mangrove forests (Besnard, 1950; Schaeffer-Novelli et al., 1990; Mendonça and Katsuragawa, 1997). The estuary was designated a national protected area in 1984 due to its ecological importance (Schaeffer-Novelli et al., 1990).

The surveyed area included the estuarine waters encircling the Cananéia island, as well as approximately $12 \mathrm{~km}$ northwards (Figure 1 ). The $132 \mathrm{~km}^{2}$ area was divided into six smaller sub-areas: A0, A1, A2, A3, A4, and $\mathrm{A} 5$. There are no biological and/or physical barriers isolating them. Sub-areas were stratified in order to cover the entire estuarine area where dolphins can be found in a lesser amount of days. Based on their sizes and daylight time available for observations, sub-areas A1 to A4 were surveyed on the same day, and A0 and A5 on two other separate days. Therefore, the entire surveyed area was covered in three days. The northern portion of the estuary has been highly influenced by freshwater from a man-made channel dug in the 1880s, closed in 1978, and re-opened in 1995 (Tommasi, 1985).

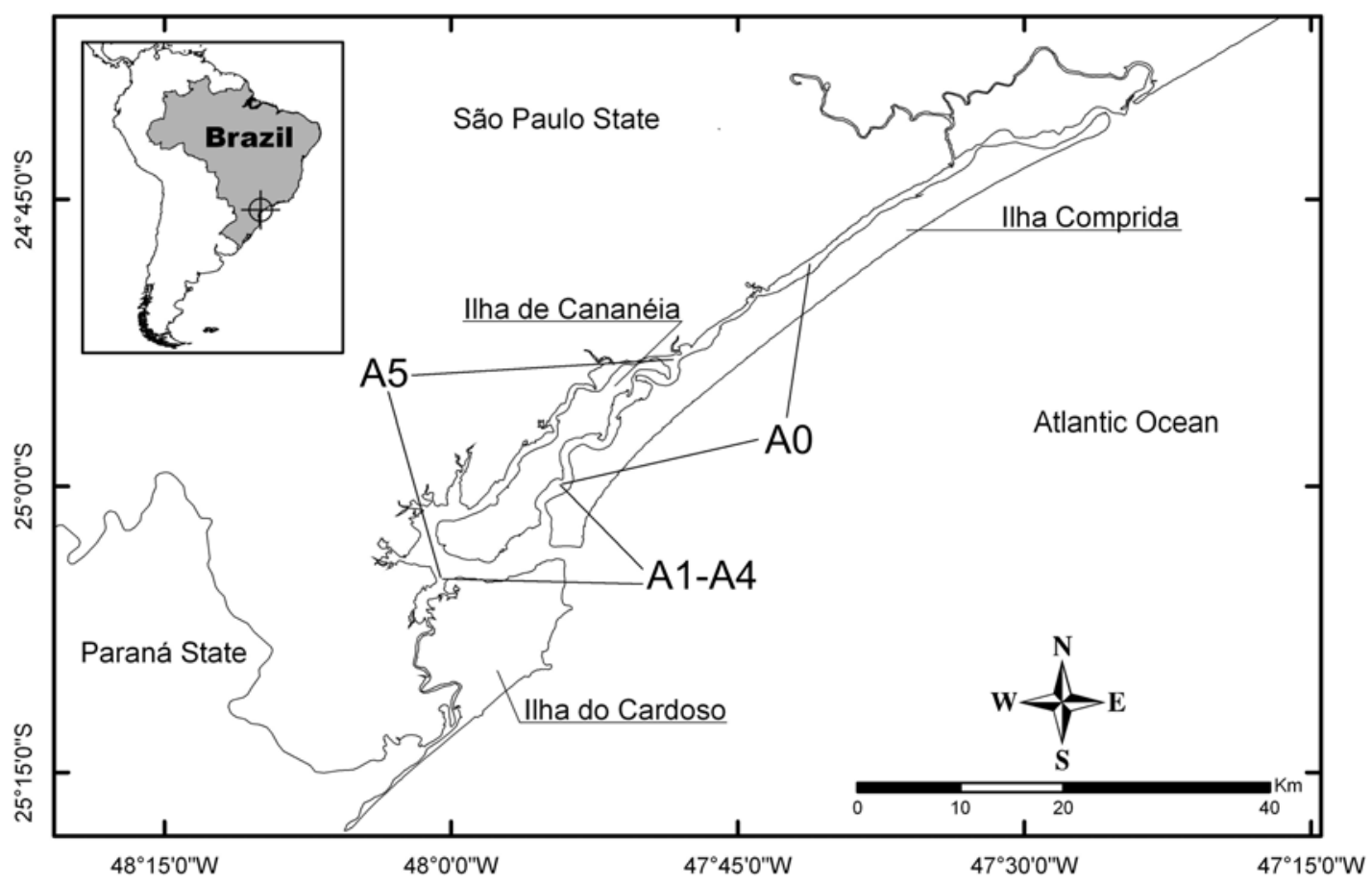

Figure 1. Map of the surveyed area where marine tucuxi dolphins (Sotalia guianensis) were studied around the Cananéia Island. Sub-areas A0 to A5 are indicated. 
As a consequence, S. guianensis can only be found up to the northern limit of sub-area A0 (Santos, 2004), which represented the northern limit of our surveyed area.

\section{Data Collection}

Boat-based (15 and 30hp motorized vessels) surveys were conducted from May 2000 to July 2003. Efforts were unevenly distributed along time and space and are summarized in Table 1 . The survey path followed a zig-zag pattern to maximize chances of encountering dolphins. Surveys were only conducted in good sea conditions (Beaufort scale $\geq 2$ ). A group of tucuxi dolphins was defined as any aggregation of two or more individuals, including female-calf pairs, observed in close proximity to each other within a radius of approximately $50 \mathrm{~m}$. These aggregations were generally, but not necessarily, engaged in similar activities. Although rarely seen, lone dolphins were also counted and included in the analyses. Two types of groups were defined: (1) with and (2) without calves. Calves were characterized to be $1 / 2$ or less than the largest individuals in the group. Surface behavior was recorded and grouped into four categories: feeding, traveling, socializing and resting (sensu Shane et al., 1986; Shane, 1990a; b). Data on these activities were collected every $5 \mathrm{~min}$ using the ad libitum sampling method (Altman, 1974; Mann, 1999).

For each surveyed group of tucuxi dolphins, water salinity, transparency, depth, and temperature at the surface were recorded. Water temperature was gathered with an alcohol thermometer $\left(1^{\circ} \mathrm{C}\right.$ scale $)$ set on the water surface for $3 \mathrm{~min}$. Water salinity was obtained from samples collected in the field and analyzed in the laboratory using a handheld refractometer ( $2 \mathrm{ppm}$ scale). Water transparency was measured through the use of a $12 \mathrm{~cm}$ radius Secchi disk. Water depth was taken every $5 \mathrm{~min}$ at the same time as behavior recordings. A portable echo-sounder with a $0.1 \mathrm{~m}$ precision was used. Seasons were divided as follows: summer (December-February), fall (March-May), winter (June-August), and spring (September-November).

Table 1. Number of survey days/observed groups of $S$. guianensis in the Cananéia estuary reported from May 2000 to July 2003 per investigated sub-area (A0 to A5).

\begin{tabular}{lcccc}
\hline \hline SUB-AREA \YEAR & 2000 & 2001 & 2002 & 2003 \\
\hline \hline A0 & $0 / 0$ & $4 / 16$ & $10 / 25$ & $10 / 30$ \\
A1 & $10 / 14$ & $12 / 18$ & $4 / 4$ & $4 / 5$ \\
A2 & $12 / 22$ & $15 / 27$ & $9 / 13$ & $2 / 3$ \\
A3 & $11 / 23$ & $21 / 37$ & $16 / 20$ & $4 / 8$ \\
A4 & $11 / 36$ & $12 / 37$ & $2 / 3$ & $4 / 6$ \\
A5 & $0 / 0$ & $0 / 0$ & $4 / 21$ & $6 / 26$ \\
Overall & $12 / 95$ & $25 / 115$ & $30 / 86$ & $20 / 78$ \\
\hline \hline
\end{tabular}

\section{Data Analysis}

Environmental data were plotted for comparisons among seasons, as well as sub-areas. The null hypothesis that there are no differences among the following parameters was tested: (1) water depth among sub-areas, (2) water temperature at surface among seasons, (3) water salinity among seasons in the same sub-area and (4) among subareas in the same season, (5) water transparency among seasons in the same sub-area and (6) among sub-areas in the same season. According to the characteristics of the gathered data (see Siegel, 1975; Zar, 1996), for investigations (1) to (4) non-parametric analyses were performed (Kruskal Wallis), and parametric tests (ANOVA) were used for the remaining investigations.

Group sizes were divided into the following categories: (1) 1 to 5 , (2) 6 to 10 , (3) 11 to 15 , (4) 16 to 20 , and (5) more than 20 individuals. Data were plotted for comparisons among subareas. To test the null hypothesis that there were no differences on group size when comparing the surveyed sub-areas, nonparametric tests (Kruskal Wallis) were performed. In order to investigate seasonal variation of group size, parametric (ANOVA) and non-parametric (Kruskal Wallis) tests were applied for sub-areas A0 and A3, respectively. Sample size was not adequate for further evaluations regarding the remaining sub-areas. A Chi-square Yates Corrected test was used to compare group composition with and without calves observed in the entire estuary.

Spearman correlation analyses were performed in order to evaluate the relationship between group size and each of the four environmental variables. Parametric and non-parametric analyses were based on Siegel (1975), Sokal and Rolf (1995) and Zar (1996), and performed using the software STATISTICA FOR WINDOWs ${ }^{\circledR} 5.0$ (StatSoft, Inc., Tulsa, OK, USA). The 5\% significance level was adopted for all tests.

\section{Results}

A total of 260 hours over 87 days were spent in surveys to study $S$. guianensis in the Cananéia estuary from May 2000 to July 2003. A total of 374 groups were seen varying from one individual to aggregations of up to 60 individuals (mean \pm SD: $12.4 \pm 11.4$ individuals). Solitary individuals were seen only seven times $(1.9 \%$ of all observations). Groups with calves (89.7\% of all observed groups) were significantly more common in all sub-areas when compared to groups without calves (Chi-square Yates Corrected $=41.14, p<0.05$ ) (Figure 2). Groups without calves were found in all sub-areas and were usually smaller and composed of up to 12 individuals.

In all sub-areas where dolphins were reported, water depth ranged from 0.5 to $23 \mathrm{~m}$ (mean \pm SD: $8.1 \pm 3.9 \mathrm{~m}$ ) (Figure 3); water temperature varied from 16 to $31^{\circ} \mathrm{C}$ (mean \pm SD: $22.2 \pm 3.5^{\circ} \mathrm{C}$ ) (Figure 4$)$; water transparency varied from 0.2 to $4 \mathrm{~m}$ (mean \pm SD: $1.8 \pm 0.8 \mathrm{~m}$ ) (Figures 5 and 6); and water salinity varied from 4 to 40ppm (mean \pm SD: $28.1 \pm 5.9 \mathrm{ppm}$ ) (Figures 7 and 8). 


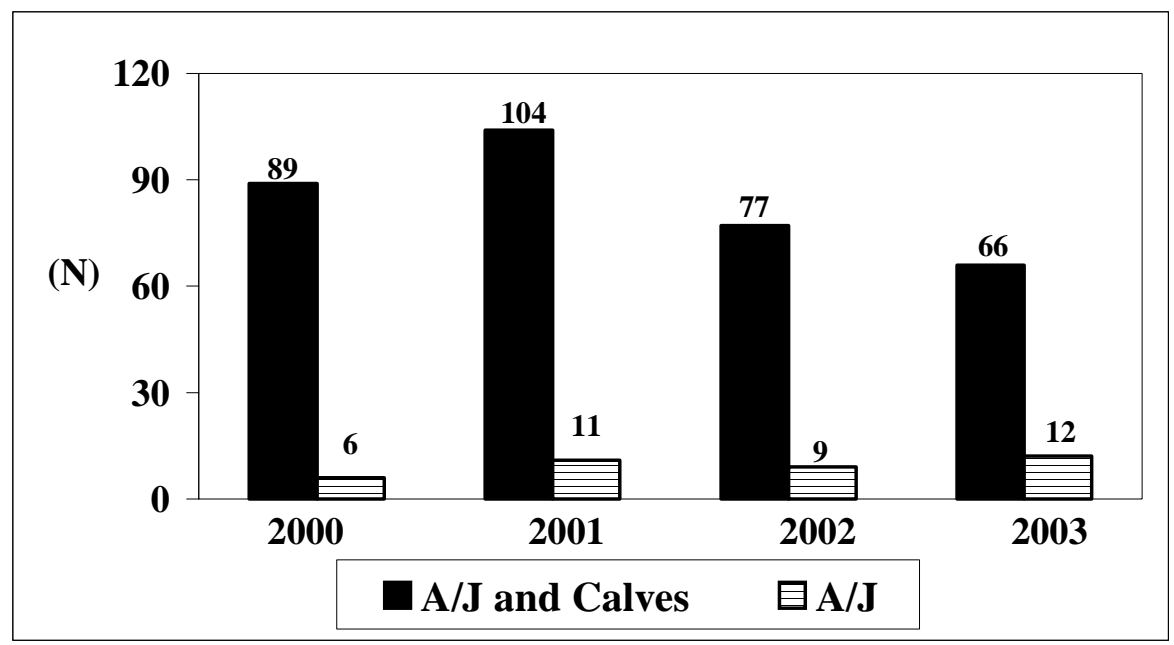

Figure 2. Group composition of marine tucuxi dolphins found in the Cananéia estuary from May 2000 to July $2003(n=374)$ based on age classes. $\mathrm{A} / \mathrm{J}$ and calves = groups with calves, and $\mathrm{A} / \mathrm{J}$ includes groups without calves.

Water Depth

Figure 3. Water depth (in meters) variation where marine tucuxi dolphins were found in the six surveyed sub-areas of the Cananéia estuary from May 2000 to July 2003. Mean (•), standard deviation (I) and standard error (bar) are represented.

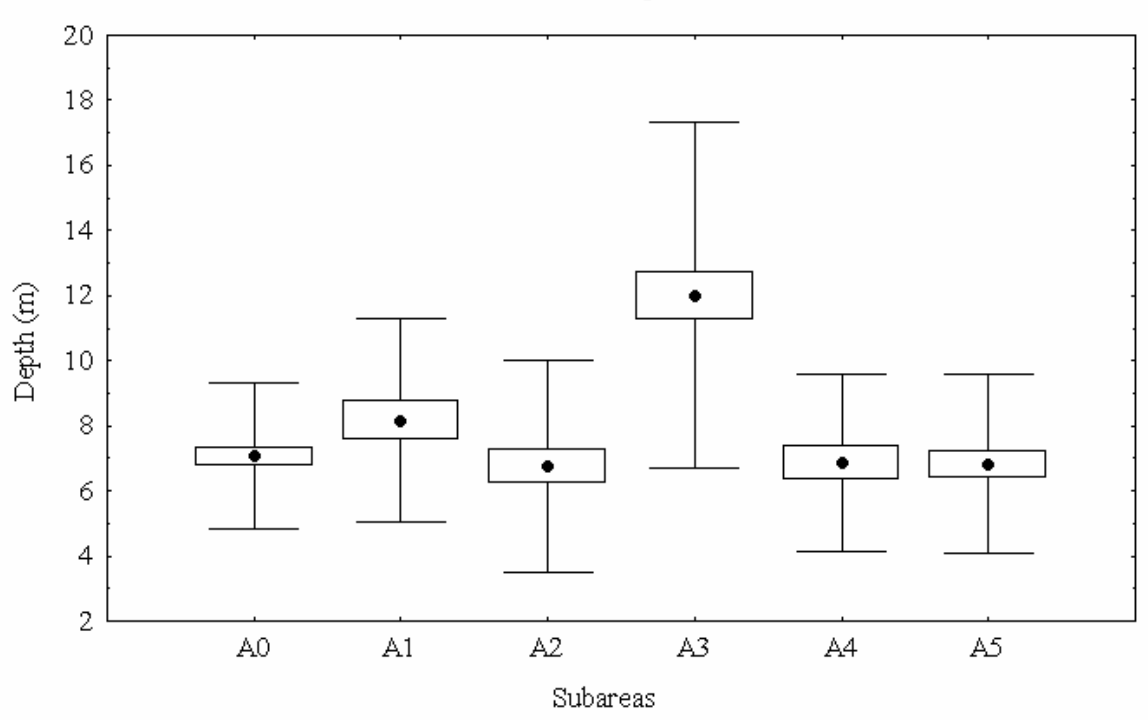

Water Temperature

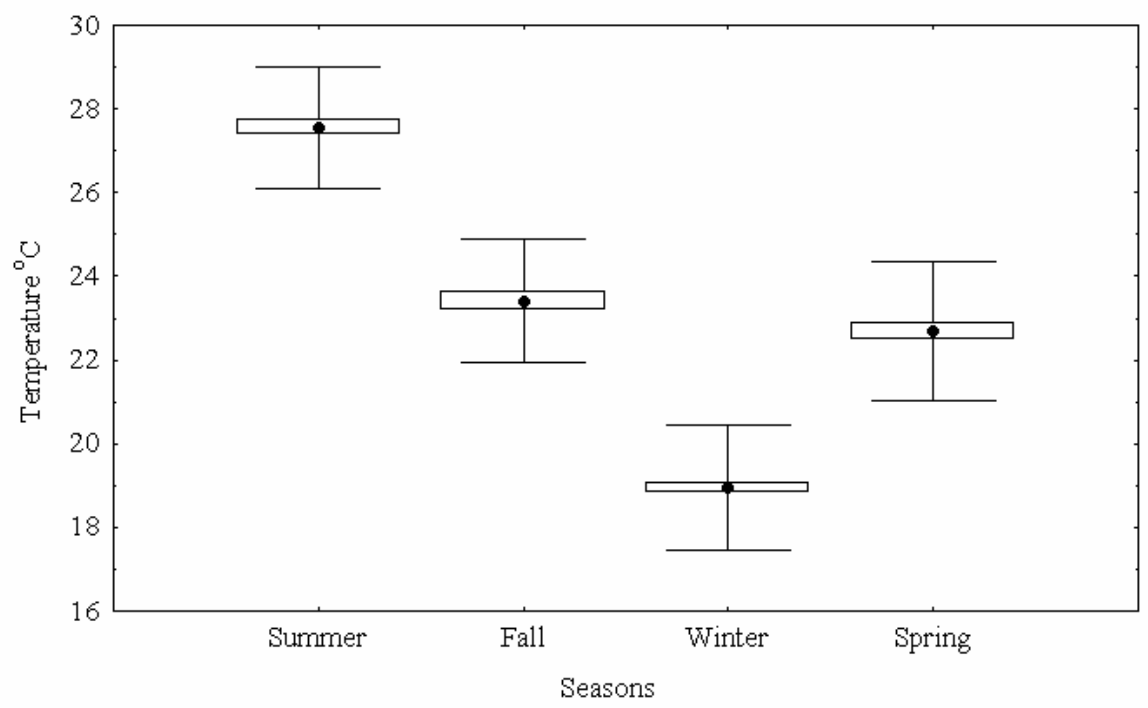

Figure 4. Seasonal water temperature $\left({ }^{\circ} \mathrm{C}\right)$ variation in the Cananéia estuary from May 2000 to July 2003. Mean (•), standard deviation (I) and standard error (bar) are represented. 
Figure 5. Water transparency (m) variation where marine tucuxi dolphins were found in the six surveyed sub-areas of the Cananéia estuary from May 2000 to July 2003. Mean (•), standard deviation (I) and standard error (bar) are represented.

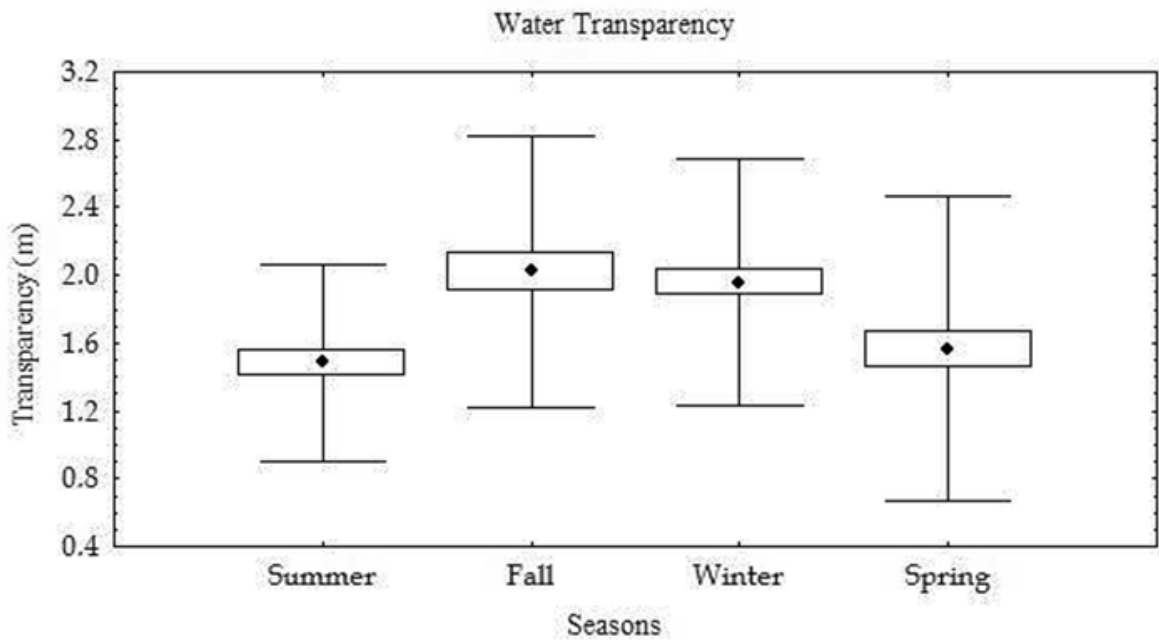

Water Transparency

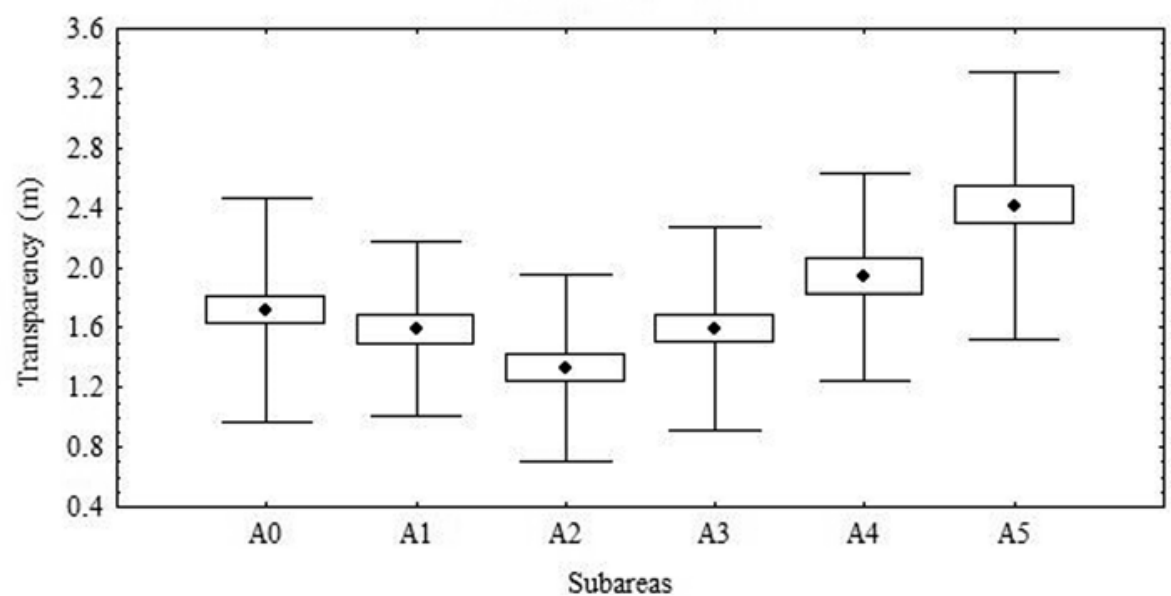

Figure 6. Seasonal water transparency $(\mathrm{m})$ variation in the Cananéia estuary from May 2000 to July 2003. Mean (•), standard deviation (I) and standard error (bar) are represented.

Water Salinity

Figure 7. Water salinity (ppm) variation where marine tucuxi dolphins were found in the six surveyed sub-areas of the Cananéia estuary from May 2000 to July 2003. Mean (•), standard deviation (I) and standard error (bar) are represented.

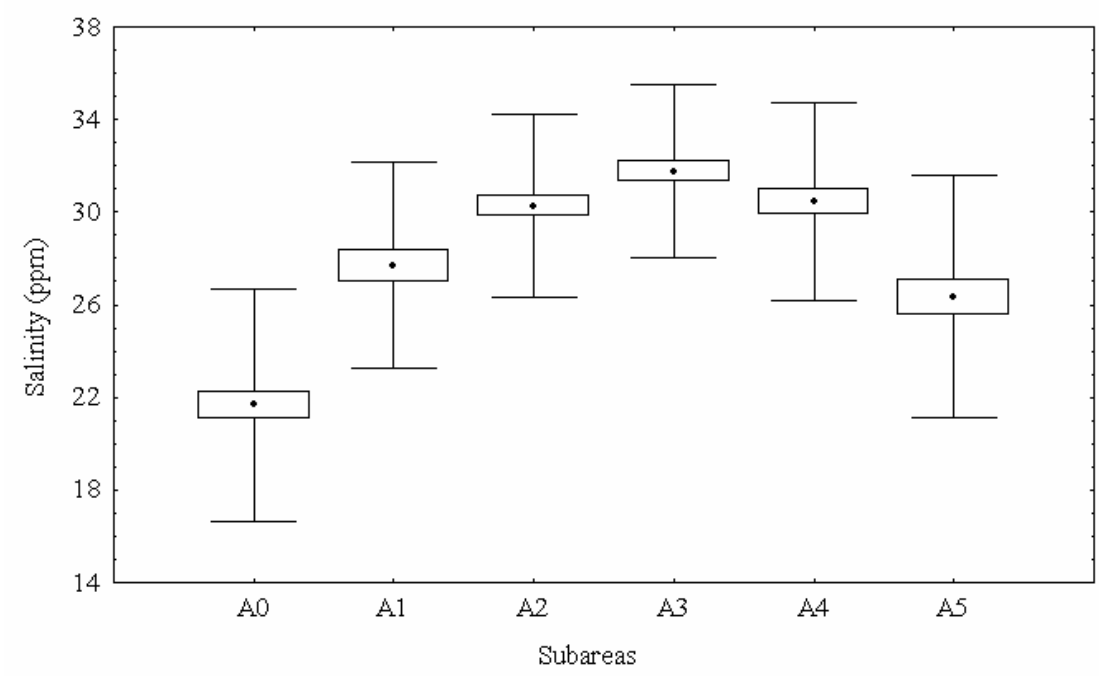


Water depth was significantly deeper at sub-area A3 (Kruskal Wallis, $\mathrm{H}=40.33, p=0.0000$ ) when compared to the other five sub-areas. No significant differences among the five remaining sub-areas were found (Kruskal Wallis, $\mathrm{H}=5.56, p=0.2345)$. No significant differences were found among water temperature values when comparing subareas (Kruskal Wallis, $\mathrm{H}=7.69, p=0.1745$ ), but expected significant differences were found among seasons (Kruskal Wallis, $\mathrm{H}=259.23, p=0.0000)$. Significant differences among sub-areas (ANOVA, $\mathrm{F}=11.89$, $p=0.0000$ ), and seasons (ANOVA, $\mathrm{F}=7.89, p=0.0000$ ) were found when analyzing water transparency values. Local waters are darker in spring and summer seasons, and in sub-areas close to the main estuary entrance (A1, A2, A3). Differences were reported when comparing salinity values among sub-areas (Kruskal Wallis, $\mathrm{H}=124.59$, $p=0.0000$ ) and seasons (Kruskal Wallis, $\mathrm{H}=49.69$, $p=0.0000$ ). Lower salinity values were usually found in inner waters in all seasons. Higher values were observed in winter, which is known as a dry season.
While marine tucuxi groups were seen in the entire surveyed area, group size varied significantly among sub-areas (Kruskal Wallis, $\mathrm{H}=36.04, p=0.0000$ ). Groups were larger in sub-area A3 (mean \pm SD: 18.3 \pm 15 individuals, $n=90$ ), the main estuary entrance, and smaller in the inland waters of sub-area A5 (mean \pm SD: $7.8 \pm 6.9$ individuals, $n=47$ ) (Table 2, Figure 9). No significant differences were observed when comparing group size among seasons for sub-areas $\mathrm{A} 0$ and A3 (A0: Kruskal Wallis, $\mathrm{H}=4.41, p=0.2199$; A3: ANOVA, F=0.58, $p=0.6302$ ).

A positive correlation between group size and environmental variables was only observed for water depth (Spearman's rank test, $\mathrm{r}=0.4716, p=0.0000$ ). Local marine tucuxis usually form large aggregations (20 to 60 individuals) when engaged in feeding and foraging activities in deeper waters found mainly in sub-area A3. S. guianensis was reported in multi-species associations with the following birds: brown boobie (Sula leucogaster), frigate bird (Fregata magnificens), terns (Sterna spp.),

Water Salinity

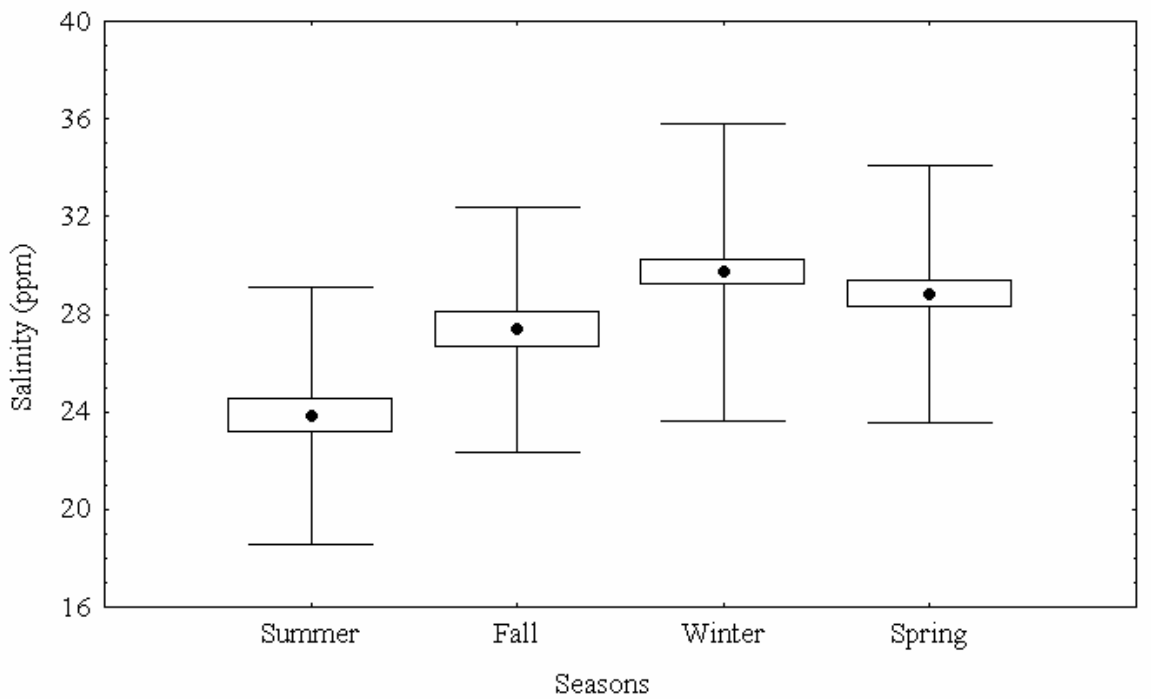

Figure 8. Seasonal water salinity (ppm) variation in the Cananéia estuary from May 2000 to July 2003. Mean (•), standard deviation (I) and standard error (bar) are represented.

Table 2. Mean group sizes of S. guianensis in the Cananéia estuary reported from May 2000 to July 2003 per investigated sub-area (A0 to A5).

\begin{tabular}{lcccc}
\hline \hline SUB-AREA & MEAN & SD & SAMPLE SIZE & RANGE \\
\hline \hline A0 & 13.5 & 11.9 & 71 & $2-60$ \\
A1 & 12.6 & 12.9 & 42 & $1-60$ \\
A2 & 10.1 & 6.9 & 66 & $1-30$ \\
A3 & 18.3 & 15.0 & 90 & $1-60$ \\
A4 & 8.2 & 4.5 & 62 & $1-23$ \\
A5 & 7.8 & 6.9 & 47 & $2-45$ \\
Overall & 12.4 & 11.4 & 378 & $1-60$ \\
\hline \hline
\end{tabular}

SD means Standard Deviation. 


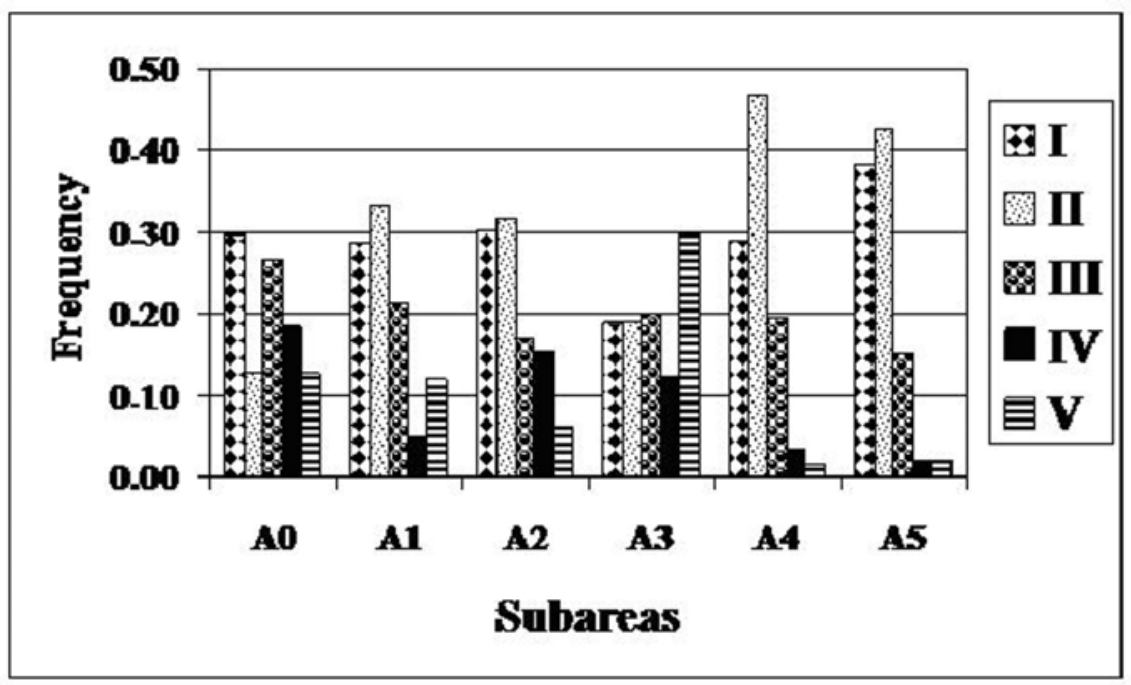

Figure 9. Frequency of marine tucuxi dolphins group sizes found in the six surveyed sub-areas in the Cananéia estuary from May 2000 to July 2003 ( $n=374$ ). Group sizes were divided into the following categories: (I) 2 to 5; (II) 6 to 10; (III) 11 to 15; (IV) 16 to 20; (V) 20+ individuals.

neotropic cormorant (Phalacrocorax brasilianus), blackbacked gull (Larus dominicanus), and white egret (Ardea alba). Associations with marine birds were more frequent in winter (Chi-square Yates Corrected $=16.3, p=0.0000)$. Water transparency was likely one of the factors that influenced the occurrence of multispecies associations between $S$. guianensis and birds in winter, when waters were significantly clearer when compared to summer and spring. The presence of prey which can be found in larger schools close to the water surface might also be another reason why such multi-species associations occur mainly in winter. Foraging and feeding strategies involving association with birds observed in sub-areas A0 and A3 were distinct, but both usually involved more than 15 individuals. In the main estuary entrance (A3) and throughout the year, the larger tucuxi aggregations usually dove in sequence and came back to the surface all together within 40 to 80 seconds. When surfacing, in some occasions several individuals had mud attached to their bodies, suggesting they dove down to the bottom (see also Santos et al., 2002). On the other hand, when feeding on sardines (Sardinella brasiliensis) in sub-area A0 in winter, dive times were reduced and aerial behaviors were common.

\section{Discussion}

The mean group size observed for tucuxi dolphins in the Cananéia estuary was $12.4 \pm 11.4$ (SD) individuals. In two previous studies conducted in a subset of the same surveyed area, investigators described groups composed of two to five individuals as most commonly found (Geise et al., 1999), and that $80 \%$ of all observed groups were composed of two or three individuals (Monteiro Filho, 2000). These studies presented information gathered from both land-based and boatbased platforms. Marine tucuxi dolphins approach two sloping beaches at the main Cananéia estuary entrance to display foraging and feeding behaviors (MonteiroFilho, 1995; Santos et al., 2000). These beaches are excellent platforms of observations as investigators can study S. guianensis without disturbance. However, through the help of the photo-identification technique, Santos (2004) showed that not all dolphins in the population display foraging and feeding behaviors close to the two mentioned beaches. In addition, mean group size observed close to the sloping beaches was 3.7 \pm 2.6 (SD) individuals $(n=126)$, which was significantly different when compared to data gathered from boats (Mann Whitney, $\mathrm{U}=436.00, p=0.005, n=500$ ). The carrying capacity of both beaches is likely the limitation for the notification of larger aggregations of tucuxi dolphins in shallower waters. As a consequence, investigators should become aware when evaluating $S$. guianensis group size not only in the Cananéia estuary, but also in other areas where it is possible to conduct land-based observations, as data collected from different platforms comparing shallow and deep waters may render different results.

Comparisons among $S$. guianensis group sizes observed along the species distribution range may be limited as different authors tend to use distinct "group" definitions. However, most definitions are similar and even with such possible limitations, it is interesting to compare different features of the ecosystems where marine tucuxi group sizes were described. Table 3 summarizes part of the known information on $S$. guianensis group size along its distribution. A brief description on the characteristics of the habitat where each study was conducted is presented. Based on the quoted information, as well as the data gathered in this 
study, it is possible to conclude that there is a tendency to find smaller tucuxi groups in protected waters and larger aggregations in open waters. This tendency has been previously described for delphinid species elsewhere (see Würsig et al., 1986; Gygax, 2002).

Many factors can dictate group size in small cetaceans including occurrence of predators, abundance and distribution of prey (which can lead to specific behavioral activities), bathymetry, and abundance of the species considered (Connor, 2000). Small-sized dolphins in open waters seem to be more vulnerable to predators and tend to form larger aggregations for their own protection, as well as to find patchy food resources in a vast area (Norris and Dohl, 1980; Gygax, 2002). To date, there is no published information on S. guianensis predators. Potentially, sharks and killer whales (Orcinus orca) may prey upon S. guianensis. In December 1992, a $5 \mathrm{~m}$ long white shark (Carcharodon carcharias) was captured $27 \mathrm{~km}$ off the Cananéia estuary. It had remains of two Atlantic spotted dolphins (Stenella frontalis) in its stomach (Siciliano et al., 19963). In recent years, a killer whale was witnessed attacking and killing a franciscana dolphin (Pontoporia blainvillei) in coastal waters of neighboring Paraná state (Santos and Netto, 2005), where marine tucuxis can also be found. On 10 September 2007, a killer whale was observed in inner Cananéia estuarine waters close to the main entrance for more than an hour. This is to date the first record of a killer whale in local inner waters. Although no evidence of interactions with $S$. guianensis was noted, further investigations should highlight if such movements may be related to a possible predation on S. guianensis. In coastal waters off Cananéia, several other species of sharks such as Carcharhinus leucas, C. obscurus, and Sphyrna sp. have been previously reported (e.g. Sadowsky, 1965; Gadig, 2001), all known to have attacked and killed cetacean species in other areas (Weller, 2002). Adult C. leucas (Sadowsky, 1971), and juvenile C. obscurus and Sphyrna lewini (present study, unpublished data) found in inner estuarine waters may also set marine tucuxi dolphins at predation risk. However, no attacks have been reported, neither have we found evidence of scars or mutilated photoidentified individuals. An investigation on the feeding habits of several shark species could render more clues on their possible interactions with $S$. guianensis.

Environmental data showed a high variability as expected for a large estuarine area in a sub-tropical region (see Figures 3-8). Of the examined variables, it is known that water salinity affects the distribution of fish (Moyle and Cech Jr., 1988). The Cananéia estuary is habitat for a large biodiversity of fish species year-round (Maciel, 2001), supplying food for S. guianensis along most part of its area. Marine tucuxi dolphins prey chiefly on bottom-dwelling sciaenid fish found in coastal and estuarine waters, as well as on seasonal schooling fish such as mullets (Mugil spp.) and sardines (S. brasiliensis) (Santos et al., 2002; Santos, 2004). In winter, large schools of sardines move northwards the surveyed estuary in the search for waters with lower salinity needed during maturation (Richardson and Sadowsky, 1960; RossiWongtschowski, 1977; Maciel, 2001). In fall and winter, the water is clear (see Results and Figure 5) as the dry season reduces the input of organic matter from land to the estuary (Schaeffer-Novelli et al., 1990). Therefore, adequate conditions for the formation of multi-species associations among marine tucuxis and birds engaged in feasting activities are present. Several bird species were observed in such associations (see results), including the white egret $(A$. alba). This is believed to be the first known feeding association between the latter and S. guianensis.

Table 3. Group size of marine tucuxi dolphins (Sotalia guianensis) along the species' range.

\begin{tabular}{lccc}
\hline \hline LOCATION & $\begin{array}{c}\text { GROUP SIZE (INDIVIDUALS) } \\
\text { (VARIATION OR MEAN } \pm \text { SD) }\end{array}$ & HABITAT & SOURCE \\
\hline \hline Baía Norte, Santa Catarina, Brazil $\left(\sim 27^{\circ} S\right)$ & 60 to 80 & open bay, close to shore, shallow & Flores (2003) \\
Babitonga Bay, Santa Catarina, Brazil $\left(\sim 26^{\circ} S\right)$ & $6.5 \pm 3.9$ & protected estuary & Cremer $(2000)$ \\
Sepetiba Bay, Rio de Janeiro, Brazil $\left(\sim 22^{\circ} S\right)$ & Aggregations of up to 200 & open bay & Simão et al. $(2000)$ \\
Parati, Rio de Janeiro, Brazil $\left(\sim 23^{\circ} S\right)$ & $32.5 \pm 19.1$ & open waters & Lodi $(2000)$ \\
Guanabara Bay, Rio de Janeiro, Brazil $\left(\sim 22^{\circ} S\right)$ & $13.5 \pm 9.5$ & protected bay & Azevedo et al. $(2000)$ \\
Abrolhos Bank, Bahia, Brazil $\left(\sim 18^{\circ} S\right)$ & $6.6 \pm 11.5$ & open shallow waters & Rossi-Santos et al. $(2006)$ \\
Cayos Miskito Reserve, Nicaragua $\left(\sim 15^{\circ} \mathrm{N}\right)$ & $3.0 \pm 1.8$ & protected estuary & Edwards and Schnell (2001) \\
Inner lagoons of Nicaragua $\left(\sim 15^{\circ} \mathrm{N}\right)$ & $8.0 \pm 6.1$ & inner lagoons & Carr and Bonde $(2000)$ \\
\hline \hline
\end{tabular}

A brief comment on habitat where the quoted studies were conducted is presented.

\footnotetext{
${ }^{3}$ Siciliano, S.; Simões-Lopes, P.C.; Amorim, A.F. ; Arfelli, C.A.; Zerbini, A.; and Santos, M.C. de O. (1996) Presença de um golfinhopintado-do-Atlântico (Stenella frontalis) no conteúdo estomacal de um tubarão-branco (Carcharodon carcharias). Addendum in Absctracts, VII Reunión de Trabajo de Espcialistas en Mamíferos Acuáticos de América del Sur, 22 - 25 October, Viña del Mar, Chile.
} 
A positive correlation between $S$. guianensis group size and water depth was observed in this study. Groups were larger in the main estuary entrance (sub-area A3). Several studies on marine tucuxi dolphins reported the formation of larger aggregations when engaged in foraging and feeding activities (e.g. Lodi, 2000; Simão et al., 2000; Flores, 2003; Azevedo et al., 2005). Larger tucuxi aggregations $(40+$ individuals) were mainly reported in sub-area A3, where it is possible to find larger concentrations of fish moving inside and outside the estuary (Maciel, 2001), and where tucuxis are usually displaying foraging and feeding activities. As a consequence, both the distribution and abundance of prey and bathymetry may be responsible for the larger mean group size observed in this sub-area. The formation of larger groups is likely needed when searching for food in deeper bodies of water in order to increase foraging success. Aggregations of up to 40 individual dolphins engaged in foraging and feeding activities were also common in sub-area A0 in winter when preying on sardines. When engaged in feeding associations close to the main estuary entrance, S. guianensis joined in up to approximately 60 individuals. In that sub-area, tucuxis were frequently observed engaging in bottom-feeding, as shown by the presence of mud attached to their bodies. Bottom-dwelling fish are not only the most abundant in the local estuary (Maciel, 2001), but also the main prey item of S. guianensis (Santos et al., 2002). On the other hand, the feeding strategy used to catch sardines in sub-area A0 in winter was different. Marine tucuxi aggregations remained in the water surface in order to encircle and capture prey in the water column, usually moving in coordinated associations which caused the splashing of water. These movements attracted birds that benefited not only by the splashing of water, but also by the water transparency reported in winter, which increases their chances of finding and catching prey. These two examples illustrate the plasticity of feeding strategies displayed by $S$. guianensis aggregations when catching prey with different habits and found in different water depths. In both circumstances, calves were always present in high numbers. Such aggregations may be important for mothers because of two distinct reasons: (1) teaching calves to catch food, and (2) counting on their congeners to help monitor their calves while they are engaged in their own chase. Groups with calves were more common in all sub-areas and along the entire survey when compared to groups without calves (see Figure 2). The latter were usually small and composed by up to 12 individuals in the entire estuary. Calving takes place throughout the year (Santos et al., 2001) and therefore it is likely that they will be seen in most groups.

Although abundance is known as one of the factors that help determine group size in small cetaceans (Connor, 2000), data on S. guianensis abundance estimates are lacking along a considerable range of the species distribution to address further comments. Based on the application of five distinct capture-recapture estimators for closed populations, Acuña (2002) estimated that the abundance of marine tucuxi dolphins in part of the Cananéia estuary ranged from 159 to 372 individuals. In addition, Santos (2004) observed that tucuxi dolphins in the Cananéia estuary temporarily merge into different groups forming casual and short-lasting associations. Therefore, it is quite possible that in a protected estuary with plenty of food resources year round, individuals may explore a larger area quite uniformly, forming temporal small and large groups depending on their demands. Descriptions on associations among marine tucuxi dolphins in other areas of the species range, as well as on abundance estimates, may help within-species comparative studies to become more consistent (see Gygax, 2002). Flexibility in intraspecific social systems must be considered since such flexibility demands behavioral mechanisms for which the individual is engaged with the environment (Lott, 1984).

After the construction of a bridge to connect the island of Cananéia to the mainland in 1998, allowing better conditions to access a preserved ecosystem, tourism has been growing in an uncontrolled manner. Tours to watch dolphins without specific regulations have been conducted since 1999, with a huge increase from 2002 on. Recent observations have shown that larger aggregations of tucuxi dolphins are no longer common in the main estuary entrance (unpublished data). The area is part of the route that boats usually take to move towards Ilha do Cardoso state park, another attraction for tourists. In summer months and holidays throughout the year, schooners and smaller boats spend almost the entire day in dolphin watching activities. As it has been shown that tucuxi calves are found year-round in all sub-areas of the estuary, unregulated tours to watch dolphins in sub-area A3 may pose some threats to their social bonds at risk when larger aggregations are engaged in feeding and foraging activities. When considering the multi-species associations in sub-area $\mathrm{A} 0$, it became clear that this area has an important role for distinct predators during winter. In the last 10 years, the northern area of the Cananéia island has been the target of several human-induced impacts such as habitat destruction for housing, illegal fishing efforts and illegal use of pesticides placing the food chain at risk in the estuary. Habitat destruction reduces biodiversity and, as a consequence, the carrying capacity of the ecosystem. Illegal fishing activities based on the use of large gillnets closing estuarine channels have been responsible for incidental captures of S. guianensis (Santos, 2004). Contaminant loads were previously reported to local tucuxis (Yogui et al., 2003) and their illegal use is still a threat. Sub-area A0 is quite far from the main inhabited area and, as a consequence, lacks adequate surveillance by the authorities. Law enforcement is urgently needed to reduce habitat destruction and the loss of biodiversity. Thus, the gathered observations in the present study based on an important element of the trophic level can be used as another important tool for the local ecosystem management and conservation. 


\section{Ackowledgements}

The Whale and Dolphin Conservation Society (from 1996 to 1998), the Society for Marine Mammalogy (1999 and 2001), and the Cetacean Society International (from 1995 to 2005) financially supported marine tucuxi photoidentification studies at the Cananéia estuary. Special thanks go to Alison Smith, Vanessa Williams, Nicola Hodgins (WDCS), Steven Swartz (SMM), and William Rossiter (CSI). The Earthwatch Institute has been financially supporting the continuation of the photoidentification studies in the Cananéia estuary since 2003. Marcos Santos received grants from Fundação de Amparo à Pesquisa do Estado de São Paulo (FAPESP) to conduct his doctoral studies (process number 01/ 05128-8) and receives grants from "Programa Jovem Pesquisador - FAPESP" (process numbers 05/594395 and $05 / 54149-9$ ). Logistic support was provided by the Instituto Oceanográfico da Universidade de São Paulo. We thank David Janiger for providing manuscripts on cetacean ecology. Dr. Otto Gadig (Projeto Cação, UNESP) kindly identified captured shark species photographed in inner estuarine waters. Dr. Jocemar Mendonça identified sardines bitten by tucuxi dolphins collected in the field. Fabiano N. Pupim prepared the map. Paulo Flores, Alexandre Azevedo, Krista Muller, Susan Shane and Denise Herzing made comments and helpful suggestions to improve the manuscript. Eduardo R. Secchi, Nélio Barros, and an anonymous reviewer made helpful comments when evaluating the final document.

\section{References}

AcuÑA, L.B. (2002) Estimativa do tamanho da população do bototucuxi marinho, Sotalia fluviatilis (Cetacea, Delphinidae) na região do estuário de Cananéia, São Paulo, por meio de catálogo de fotoidentificação para a espécie. M.Sc. Thesis. Universidade de São Paulo, SP, Brazil. 73pp.

Altmann, J. (1974) Observational study of behavior: sampling methods. Behaviour 49: 227-267.

Azevedo, A.F., Laílson-Brito, J., Cunha, H.A. and Van Sluys, M. (2004) A note on site fidelity of marine tucuxis (Sotalia fluviatilis) in Guanabara bay, southeastern Brazil. Journal of Cetacean Research and Management 6: 265-268.

Azevedo, A.F., Viana, S.C, Oliveira, A.M. and Van Sluys, M. (2005) Group characteristics of marine tucuxis (Sotalia fluviatilis) in Guanabara bay, south-eastern Brazil. Journal of the Marine Biological Association, U. K. (London) 85: 209-212.

Besnard, W. (1950) Considerações gerais em torno da região lagunar de Cananéia-Iguape I. Boletim do Instituto Paulista de Oceanografia, São Paulo 1: 9-26.

Caballero, S., Trujillo, F., Vianna, J.V., Barrios-Garrido, H., Montiel, M.G., Beltrán-Pedreros, S., Marmontel, M., Santos, M.C.O., Rossi-Santos, M, SAntos, F.R. And BAKER, S.C. (2007) Taxonomic status of the genus Sotalia: species level ranking for "tucuxi" (Sotalia fluviatilis) and "costero" (Sotalia guianensis) dolphins. Marine Mammal Science 23: 358-386.
CARR, T. AND BONDE, R.K. (2000) Tucuxi (Sotalia fluviatilis) occurs in Nicaragua, $800 \mathrm{~km}$ north of its previously known range. Marine Mammal Science 16: 447-452.

Connor, R.C. (2000) Group living in whales and dolphins. Pages 199-218 in Mann, J., Connor, R.C., TYaCK, P.L. And WhiteHeAd, H (Eds) Cetacean Societies: Field studies of Dolphins and Whales. University of Chicago Press, Chicago, IL, USA.

Cremer, M. J. (2000) Ecologia e conservação do golfinho Sotalia fluviatilis guianensis (Cetacea: Delphinidae) na Baía da Babitonga, litoral norte de Santa Catarina. M.Sc. Thesis. Universidade Federal de São Carlos, SP, Brazil. 227pp.

Cunha, H.A., da Silva, V.M.F., Lailson-Brito, J. Santos, M.C.O., Flores, P.A.C., Martin, A.R., Azevedo, A.F., Fragoso, A.B.L., Zanelatto, R.C. and Solé-Cava, A.M. (2005) Riverine and marine ecotypes of Sotalia dolphins are different species. Marine Biology 148: 449-457.

Da Silva, V.M.F. AND Best, R.C. (1996) Sotalia fluviatilis. Mammalian Species 527: 1-7.

Day Jr, J.W., Hall, C.A.S., KemP, W.M. and YaÑez-Arancibia, A. (1989) Estuarine Ecology. $1^{\text {st }}$ Edition. John Wiley and Sons, Inc., NY, USA. 576pp.

EdwARds, H.E. AND Schnell, G.D. (2001) Status and ecology of Sotalia fluviatilis in the Cayos Miskito Reserve, Nicaragua. Marine Mammal Science 17: 445-472.

Favaro, E.G.P. (2004) Utilização da Baía dos Golfinhos (Pipa $R N)$ pelo boto Sotalia fluviatilis (Cetacea: Delphinidae). M.Sc. Thesis. Universidade Federal de Pernambuco, Recife, PE, Brazil. 42pp.

Flores, P.A.C. (1999) Preliminary results of a photoidentification study of the marine tucuxi Sotalia fluviatilis in southern Brazil. Marine Mammal Science 15: 840-847.

FLores, P.A.C. (2002) Tucuxi Sotalia fluviatilis. Pages 1267-1269 in Perrin, W.F., Würsig, B. And Thewissen, J.G.M. (Eds) Encyclopedia of Marine Mammals. Academic Press, San Diego, CA, USA.

FLORES, P.A.C. (2003) Ecology of the marine tucuxi dolphin (Sotalia fluviatilis) in southern Brazil. Ph.D. Thesis. Pontifícia Universidade Católica do Rio Grande do Sul, Porto Alegre, RS, Brazil. 140pp.

Flores, P.A.C. AND Bazallo, M. (2004) Home ranges and movement patterns of the marine tucuxi dolphin, Sotalia fluviatilis, in Baía Norte, Southern Brazil. The Latin American Journal of Aquatic Mammals 3: 37-52.

Flores, P.A.C. And Fontoura, N. (2006) Ecology of marine tucuxi, Sotalia guianensis, and bottlenose dolphin, Tursiops truncatus, in Baía Norte, Santa Catarina state, southern Brazil. The Latin American Journal of Aquatic Mammals 5: 105-115.

Gadig, O.B.F. (2001) Tubarões da costa brasileira. Ph.D. Thesis, Universidade Estadual Paulista "Júlio de Mesquita Filho", UNESP, Rio Claro, SP, Brazil. 378pp.

GeISE, L., Gomes, N. AND CERQUeIRA, R. (1999) Behaviour, habitat use and population size of Sotalia fluviatilis (Gervais, 1853) (Cetacea, Delphinidae) in the Cananéia estuary region, São Paulo, Brazil. Revista Brasileira de Biologia 59: 83-194.

GYGAX, L. (2002) Evolution of group size in the dolphins and porpoises: interspecific consistency of intraspecific patterns. Behavioral Ecology 13: 583-590. 
IUCN (2006) 2006 IUCN Red List of Threatened Species. <http:/ /www.iucnredlist.org>. Downloaded on 27 October 2007.

LodI, L. (2000) Uso de habitat e preferências do boto-cinza, Sotalia fluviatilis (Cetacea, Delphinidae), na Baía de Paraty, Rio de Janeiro. M.Sc. Thesis. Universidade Federal Rural do Rio de Janeiro, RJ, Brazil. 167pp.

LOTT, D.F. (1984) Intraspecific variation in the social systems of wild vertebrates. Behaviour 88: 266-325.

MACIEL, N.A.L. (2001) Composição, abundância e distribuição espaçotemporal da ictiofauna do complexo estuarino-lagunar de IguapeCananéia, São Paulo, Brasil. Ph.D. Thesis. Instituto Oceanográfico da Universidade de São Paulo, SP, Brazil. 252pp.

MANN, J. (1999) Behavioral sampling methods for cetaceans: a review and critique. Marine Mammal Science 15: 102-122.

Mendonça, J.T. and Katsuragawa, M. (1997) Desembarque da pesca costeira em Cananéia, São Paulo, Brasil, durante 1995 e 1996. Nerítica 11: 165-190.

Monteiro Filho, E.L.A. (1995) Pesca interativa entre o golfinho Sotalia fluviatilis guianensis e a comunidade pesqueira da região de Cananéia. Boletim do Instituto de Pesca 22: 15-23.

Monteiro Filho, E.L.A. (2000) Group organization of the dolphin Sotalia fluviatilis guianensis in an estuary of southeastern Brazil. Ciência e Cultura 52: 97-101.

Monteiro Filho, E. L. A., Monteiro, L. R. and dos Reis, S. F. (2001) Skull shape and size divergence in dolphins of the genus Sotalia: a tridimensional morphometric analysis. Journal of Mammalogy 83: 125-134.

Moyle, P. B. \& Cech Jr, J. J. (1988) Fishes: An Introduction to Ichthyology. Prentice Hall, NJ, USA. 368pp.

NorRIS, K.S. AND DoHL, T.P. (1980). The structure and functions of cetacean schools. Pages 211-261 in Herman, L.M (ED). Cetacean Behavior: Mechanisms and Functions. John Wiley \& Sons, New York, NY, USA.

Pivari, D. AND Rosso, S. (2005) Whistles of small groups of Sotalia fluviatilis during foraging behavior in southeastern Brazil. Journal of the Acoustical Society of America 118: 2725-2731.

Reeves, R.R., Smith, B.D., Crespo, E.A AND di SciAra, G.N. (Eds) (2003) Dolphins, Whales and Porpoises: 2002-2010 Conservation Action Plan for the World's Cetaceans. The World Conservation Union, IUCN, Gland, Switzerland. 147pp.

Richardson, I.D. AND SADOWSKY, V. (1960) Note on the sampling of sardine (Sardinella allecia) at Cananéia, State of São Paulo, Brazil. Boletim do Instituto Oceanográfico, São Paulo 6: 87-97.

Rossi-Santos, M., Wedekin, L.L. and Sousa-Lima, R.S. (2006) Distribution and habitat use of small cetaceans off Abrolhos Bank, Eastern Brazil. The Latin American Journal of Aquatic Mammals 5: 23-28.

Rossi-WongtschowsKI, C.L.D.B. (1977) Estudo das variações da relação peso total/comprimento total em função do ciclo reprodutivo e comportamento de Sardinella brasiliensis (Steindachner, 1879) da costa do Brasil entre $23^{\circ} \mathrm{S}$ e $28^{\circ} \mathrm{S}$. Boletim do Instituto Oceanográfico, São Paulo 26: 131-180.

SADOWSKY, V. (1965) The hammerhead sharks of the littoral zone of São Paulo, Brazil, with the description of a new species. Bulletin of Marine Science 15: 1-12.

SADOWSky, V. (1971) Notes on the bull shark Carcharhinus leucas in the lagoon region of Cananéia, Brazil. Boletim do Instituto Oceanográfico, São Paulo 20: 71-78.

SANTOS, M.C. DE O. (2004) Uso de área e organização social do bototucuxi marinho, Sotalia fluviatilis (Cetacea, Delphinidae), no estuário de Cananéia. Ph.D. Thesis. Instituto de Biociências, Universidade de São Paulo, SP, Brazil. 265pp.

Santos, M.C. De O., Rosso, S., Siciliano, S., Zerbini, A., Zampirolli, E., Vicente, A.F. And Alvarenga, F. (2000) Behavioral observations of the marine tucuxi dolphin (Sotalia fluviatilis) in São Paulo estuarine waters, Southeastern Brazil. Aquatic Mammals 26: 260-267.

Santos, M.C. De O., Acuña, L.B. And Rosso, S. (2001) Insights on site fidelity and calving intervals of the marine tucuxi dolphin (Sotalia fluviatilis) in south-eastern Brazil. Journal of the Marine Biological Association, U. K. (London) 81:1049-1052.

Santos, M.C. De O., Rosso, S., Santos, R.A., Lucato, S.H.B. and BAssoI, M. (2002) Insights on small cetacean feeding habits in southeastern Brazil. Aquatic Mammals 24: 35-48.

Santos, M.C. de O., Rosso, S. and Ramos, R.M.A. (2003). Age estimation of marine tucuxi dolphins (Sotalia fluviatilis) in south-eastern Brazil. Journal of the Marine Biological Association, U. K. (London) 83: 233-236.

Santos, M.C. De O. and NetTo, D.F. (2005) Killer whale (Orcinus orca) predation on a franciscana dolphin (Pontoporia blainvillei) in Brazilian waters. The Latin American Journal of Aquatic Mammals 4: 69-72.

Schaeffer-Novelli, Y., Mesquita, H.S.L. and Cintrón-Molero, G. (1990) The Cananéia lagoon estuarine system, São Paulo, Brazil. Estuaries 13: 193-203.

SHANE, S .H. (1990a). Behavior and ecology of the bottlenose dolphin at Sanibel Island, Florida. Pages 245-265 in Leatherwood, S. ANd Reeves, R.R. (Eds) The Bottlenose Dolphin. Academic Press, San Diego, CA, USA.

Shane, S .H. (1990b) Comparison of bottlenose dolphin behavior in Texas and Florida, with a critique of methods for studying dolphin behavior. Pages 541-558 in LeATHERWOOD, S. and ReEves, R.R. (Eds) The Bottlenose Dolphin. Academic Press, San Diego, CA, USA.

Shane, S.H., Wells, R.S. And WÜRSIG, B. (1986) Ecology, behavior and social organization of the bottlenose dolphin: a review. Marine Mammal Science 2: 34-63.

Siegel, S. (1975) Estatística Não-Paramétrica para as Ciências do Comportamento. Editora McGraw-Hill Ltda, São Paulo, SP, Brazil. 348pp.

Simão, S.M., Pizzorno, J.L.A., PerRy, V.N. AND Siciliano, S. (2000) Aplicação da técnica de fotoidentificação do boto-cinza, Sotalia fluviatilis (Cetacea, Delpnihidae) da Baía de Sepetiba. Floresta e Ambiente 7: 31-39.

SOKaL, R.R. AND Rolf, F.J. (Eds.) (1995) Biometry: The Principles and Practice of Statistics in Biological Research. W. H. Freeman and Company, $3^{\text {rd }}$ Edition, New York, NY, USA. 887pp.

Tommasi, L.R. (1985) Projeto Valo Grande. Boletim do Instituto Oceanográfico, São Paulo 3: 27-31.

WelLer, D.W. (2002) Predation on marine mammals. Pages 985994 in Perrin, W.F., Würsig, B. and Thewissen, J.G.M. (Eds) Encyclopedia of Marine Mammals. Academic Press, San Diego, CA, USA. 
WÜRSIG, B. (1986) Delphinid foraging strategies. Pages 347-359 in Schusterman, R.J., Thomas, J.A. and Wood, F.G. (Eds). Dolphin Cognition and Behavior: a Comparative Approach. Lawrence Erlbaum Associates, Hillsdale, NJ, USA.

Yogui, G.T., Santos, M.C. DE O. and Montone, R.C. (2003)
Chlorinated pesticides and polychlorinated biphenyls in marine tucuxi dolphins (Sotalia fluviatilis) from the Cananéia estuary, southeastern Brazil. The Science of the Total Environment 312: 67-78.

ZAR, J.H. (1996) Biostatistical Analysis. Englewood Cliffs, Prentice Hall, NJ, USA. 620pp. 